Ружица Радојчић

Универзитет у Београду

Филолошки факултет

Катедра за славистику

ruzicaradojcic1@gmail.com
УДК 811.161.1:811.163.41::341.76

https://doi.org/10.18485/slavistika.2021.25.2.8

Оригиналан научни рад примљено 30.7.2021.

прихваћено за штампу 6.10.2021.

\title{
ЛИНГВИСТИЧКЕ КАРАКТЕРИСТИКЕ РУСКОГ И СРПСКОГ ДИПЛОМАТСКОГ ДИСКУРСА
}

Рад се бави основним лексичким, морфолошким, синтаксичким и стилистичким карактеристикама руског и српског језика у дипломатској сфери употребе. С обзиром на своје специфичности, језик дипломатије, као подстил административног функционалног стила, представља нормирани систем језичких јединица са специјалном употребом чија се функција огледа првенствено на пољу међународних односа и комуникације, што обухвата у првом реду дипломатску кореспонденцију, документацију, разговоре и преговоре. На лексичком нивоу у оба језика присутне су лексеме словенског и несловенског порекла (најчешће латинског и француског). На семантичком и ситилистичком плану карактерише их дипломатска етикеција, као и прецизност, тактичност, уздржаност, толеранција. Морфолошки ниво језика дипломатије у оба језика одликује се употребом девербативних именица, изведених предлога најчешће са генитивом и инструменталом, као и стереотипних конструкција карактеристичних за вербалне ноте. Употреба облика императива знатно је ређа и детерминисана је специфичним контекстом. На синтаксичком нивоу карактеристична је употреба партиципа у руском језику, док се у оба језика уочавају конструкције са инфинитивом или да-конструкција за изражавање циља, као и теличне, кондиционалне, концесивне и декларативне реченице.

Анализу вршимо у циљу утврђивања најважнијих карактеристика дипломатског дискурса на свим језичким нивоима, специфичних терминолошких јединица и њиховог настанка, најчешћих стереотипних конструкција у оба језика, као и дефинисања преводних еквивалената у српском језику.

Кључне речи: језик за специјалне циљеве (LSP), језик дипломатије, стереотипне конструкциje, етикеција, лексика, морфологија, синтакса, стилистика, преводни еквиваленти.

This paper discusses lexical, morphological, syntactic and stylistic features of the Russian and Serbian languages for specific purposes, more specifically the area of diplomacy.

Bearing in mind its specificities, the language of diplomacy as a substyle of the administrative functional style is a standardized system of language units with specific usage, whose function is first and foremost reflected in the field of international relations and communications. This primarily includes diplomatic correspondence, documentation, dialogues and negotiations.

At the lexical level, lexemes of Slavic and non-Slavic origin are present (most frequently of Latin and French) in both languages. Semantically and stylistically, they are characterized by the diplomatic etiquette, as well as by precision, tact, restraint and tolerance.

The morphological level of the language of diplomacy in both languages is characterized by the use of deverbal nouns, derived adverbs - most often with the genitive and instrumental cases, as well as by stereotypical constructions specific for verbal communication. The use of the imperative form is much rare and is determined by a specific context.

At the syntactic level, the use of the participle is characteristic of Russian, while constructions with the infinitive or $d a$-constructions for expressing the aim, as well as telic, conditional, concessive and declarative clauses are typical of Serbian. 
The analysis was conducted with the aim to determine the most important features of diplomatic discourse on all linguistic levels, specific terminological units and their origin, the most frequent stereotypical constructions in both languages and to define the equivalents in Serbian.

Keywords: Language for specific purposes (LSP), language of diplomacy, stereotypical constructions, conversational etiquette, lexis, morphology, syntax, stylistics, translation equivalents.

Језик дипломатије као предмет нашег интересовања спада у домен језика струке и делимично задире у терминолошка проучавања. Лингвистичком анализом термина током дужег периода бавила се лексикологија. Испрва се под терминологијом подразумевала лексика техничких и природних наука, да би се временом почела тумачити као подсистем лексике књижевног језика са својом специјалном функцијом номинације појмова, односно као уређени скуп лексема са специјалном употребом у оквиру различитих области људских знања, науке или струке. В. П. Даниленко наводи готово две десетине дефиниција термина, истичући да овај број није коначан (Даниленко 1977: 83-86). Бавећи се питањима термина и терминологије, Лејчик дефинише термин као лексичку јединицу језика за специјалне (специфичне) циљеве, која изражава конкретни или апстрактни теоријски појам неке од области науке, знања или делатности (Лейчик 2009: 31-32).

Током низа година у русофоној средини присутна су истраживања из области терминолошке синонимије, хомонимије, антонимије, полисемије, односно метафоризације и метонимизације као процеса настанка термина. Лексичкосемантичким особинама, творбом и мотивисаношћу термина бавили су се В. В. Виноградов, О. С. Ахманова, Г. О. Винокур, А. А. Реформатски, И. Р. Гаљперин, Р. Ј. Кобрин, Т. Л. Канделаки, В. М. Лејчик, В. П. Даниленко, А. В. Суперанска, Н. В. Подољска, Н. В. Васиљева и многи други. На домаћем терену сличним лексиколошким и терминолошким истраживањима бавили су се М. Ивић, П. Ивић, П. Пипер, Д. Гортан-Премк, И. Клајн, М. Пешикан, Д. Кликовац, Р. Драгићевић, К. Кончаревић, С. Ристић, Е. Фекете, Д. Шипка и други.

Све чешћа су истраживања у области језика струке, односно језика за специфичне циљеве (LSP - Language for specific purposes), као и контрастивна проучавања језика струке и језика опште комуникације (LGP - Language for General Purpose), што уједно ствара и потребу за већим бројем речника и приручника у вези са терминологијом различитих струка (Авербух 2006: 237). У вези са тим треба скренути пажњу на чињеницу да се термин одликује прецизношћу и управо ова његова особина сужава могућност настанка не само синонимичних, већ и полисемичних терминолошких јединица (Даниленко 1977: 210).

Лексика дипломатске струке спада у струковни функционалностилски комплекс (Кончаревић 2014: 19-21). Као подстил административног (административно-пословног) функционалног стила врши своју основну функцију саопштавања. То је нормирани систем језичких јединица са специјалном употребом, чија се функција огледа првенствено на пољу међународних односа и комуникације, што у првом реду обухвата дипломатску кореспонденцију, документацију, разговоре и преговоре. Сходно томе, појам дискурса овде схватамо као скуп текстуалних форми обједињених истом функцијом и темом. У овом раду бавићемо се основним лексичким, морфолошким, синтаксичким и стилистичким карактеристикама руског и српског дипломатског дискурса. 
Са једне стране, једна од карактеристика административног функционалног стила јесте прескриптивност, што подразумева одређени лексички формализам и клише (Кожина и др. 2011: 320). Са друге стране, у језику дипломатије прескриптивност је слабије изражена, иако је употреба језичких клишеа обавезна у одређеним видовима комуникације, попут вербалних нота, о којима ће бити речи нешто касније. Дипломатски дискурс можемо поимати и као језичку реалност званичног институционализованог карактера, али свакако би фразеологију канцеларијског пословања требало диференцирати од терминологије карактеристичне за дипломатску кореспонденцију, пре свега због њене специфичне сврхе, намене и задатака.

Главни задатак дипломатије састоји се у решавању међународних питања мирним путем. У домен дипломатије спадају и питања унутрашње и спољне безбедности, очување националних вредности и интереса, као и међународног поретка, стога и професионалне обавезе дипломате подразумевају активно или пасивно учешће на међународним саветовањима, конференцијама, преговорима. Поред преписке, дипломатија подразумева и рад на документима који се упућују не само Влади, Министарству спољних послова и одређеним институцијама државе пријема (руски: принимающее государство или государство пребывания) и државе слања / именовања (руски: аккредитующее государство), већ и представницима других земаља у држави пријема. Дипломатски дискурс подразумева и друге функције од којих су најчешће комуникативна, апелативна и репрезентативна. Од великог је значаја адекватно вођење усмене и писмене дипломатске комуникације са ресорним министарством у земљи пријема, као и са дипломатама других држава, како у формалној, тако и у неформалној атмосфери. Дипломатска комуникација подразумева вербални и невербални облик.

Фокус нашег интересовања усмерићемо на вербално дипломатско општење и његове лингвистичке карактеристике. Намера нам је да евидентирамо најважније одлике језика дипломатије на свим језичким нивоима у оба језика, специфичне терминолошке јединице и начине њиховог настанка, уобичајене стереотипне конструкције, као и њихове преводне еквиваленте.

Већ смо поменули да се језик дипломатије у првом реду одликује специфичном употребом лексичких средстава. Језичким клишеима и стереотипним фразеолошким конструкцијама изражава се етикеција у комуникацији. Дипломатски тон подразумева асертивност, одмереност израза за сваку конкретну ситуацију, као и прецизност изражавања. У одмереном протоколарном тону преписке требало би избегавати непотребно нагомилавање епитета.

Последњих пар деценија уочавају се извесне промене у језику савремене дипломатије, што је неминовна последица глобалних измена на нивоу геополитике и међународних односа. Приметан је и утицај лингвистичких карактеристика савремених медија на језик дипломатије.

Најпогоднији корпус за проучавање лингвистичких карактеристика дипломатског дискурса јесу дипломатска документа у која спадају пре свега: а) личне ноте, б) вербалне ноте, в) ед-мемоар (Aide-mémoire или Non-papier), г) меморандум. Нашу пажњу задржаћемо на вербалним нотама, дипломатским документима којима се успостављају и одржавају званични контакти у првом реду између амбасаде и министарства спољних послова земље пријема. 
Вербална нота је дипломатски документ са меморандумом и печатом, састављен у трећем лицу једнине. Предмет ноте може обухватати шири спектар питања, попут информација о доласку новог шефа дипломатске мисије, обавештавања о детаљима предаје акредитивних писама, молби за издавање одговарајућих докумената члановима породице дипломате у земљи пријема, регистрације службеног возила, успостављања или унапређивања политичке, економске, културне сарадње, изражавања протеста, саучешћа, информација о званичним посетама делегација и слично (Лойко 2007: 9-10).

Посебно је важно водити рачуна о протоколарним комплиментима на почетку и на крају ноте, осим у случајевима када се нотом саопштава о проглашењу дана жалости, изјави саучешћа, или у неким од протестних нота, када се комплименти избегавају, или су сведени на минимум.

Поред поменутих карактеристика, нота подразумева и екстралингвистичке факторе, попут познавања важнијих специфичности конкретне земље, односно културолошких и лингвокултуролошких чињеница које се односе на одлике менталитета, обичаје и традицију. Када је реч о лексици која није пожељна у језику дипломатије, поменућемо употребу модалних глагола мочь, сметь модалних предикатива нужно, можно, нельзя у руском језику, односно морати, моћи, смети, као и пасивних конструкција мора се, не сме се у српском језику. Уместо нужно, може се употребити важно (важно восстановить/ укрепить двусторонние отношения). Облик императива није пожељан или се изоставља, осим у случају када је употребљен у форми инфинитива.

Кадаје реч о лексичком нивоу језика дипломатије, осврнућемо се на етимологију, неке стилске карактеристике, као и на начин настанка појединих лексема.

За лексички ниво дипломатског дискурса карактеристична је употреба терминолошких јединица словенског и несловенског порекла (најчешће латинског и француског). С обзиром на то да је француски језик дуго сматран језиком дипломатије (у средњем веку претходио му је латински, док га у новије време смењује енглески), у руском и српском дипломатском дискурсу присутни су латинизми и галицзми. Међу позајмљеницама из латинског језика честе су монолексемне и полилексемне јединице: вето, персона грата, персона нон грата, статус-кво (у српском језику: вето, персона грата, персона нон грата, статус кво). Из француског језика позајмљене су лексеме: агреман, атташе, консул, шарже д' афер, конвенция, демари, коммюнике, визит, протокол (у српском језику такође: агреман, аташе, конзул, конвениија, демари, комини$\kappa е$, протокол), мада се последња може сматрати позајмљеницом из латинског

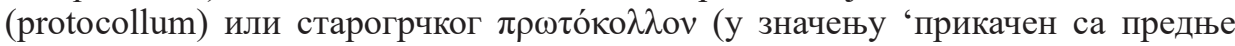
стране'). У српском језику за калк са француског ед-мемоар (Aide-mémoire) користи се и лексема подсетник или латинизам промемориа, док за исти појам руски језик користи свој израз памятная записка. Неки термини су словенског порекла у руском језику: чрезвычайный и полномочный посол, советник, поверенный в делах (последњи је знатно чешћи од позајмљенице шарже д’ афер, која се такође употребљава за функцију отправника послова), посольство, верительная грамота и сл. У српском су такође словенског порекла: саветник, отправник послова (готово да се не употребљава позајмљеница chargé d'affaires), изванредни и опуномоћени амбасадор. У новије време лексема амбасадор не- 
ретко се поима као англицизам. Ипак, детаљније залажење у етимологију говори да је реч о галицизму, а заправо највероватније о латинском Ambactus, или старовисоконемачком ambaht у значењу 'служење'. Израз верительная грамоma је латинског порекла, што потврђује и српски језик, где је у употреби латинизам акредитиви, или синтагма акредитивно писмо (од латинског асcredere у значењу 'веровати, давати веру'). Када је реч о придевско-именичким или именичко-именичким синтагмама, током XX века активно су били у употреби изрази холодная война, железный занавес, Движение неприсоединения, активное мирное сосуществование, од којих су неки постали део историје (српски: хладни рат, гвоздена завеса, Покрет несврстаности, мирољубива активна коегзистеничија).

Честа је појава да лексеме из језика опште комуникације, односно из језика правне или војне струке постају терминолошке јединице језика дипломатије, као што су содействие, невмешительство, сторона (српски: помоћ/садејство, немешање, страна), высокий представитель (српски: високи представник), правопреемство государств (српски: сукиесија држава) и слично.

Прелазећи границу између лексичког и морфолошког језичког нивоа, поменућемо његове најважније карактеристике у језику дипломатије. Скренућемо пажњу на употребу девербативних именица, попут: соглашение, решение, запрещчение, нераспространение, разоружение, предотвращение, развитие, гарантии, запрет и сл. У српском језику еквиваленти су такође девербативне именице споразум, одлука, забрана, неширење, разоружавање, спречавање, развој, гаранције, забрана. Такође је честа употреба апстрактних именица женског рода насталих суфиксацијом (додавањем суфикса -оcmb): безопасность, стабильность, договорённость (српски: безбедност, стабилност, договор/споразум), као и девербативних именица средњег рода са суфиксима -(e)нuі-, односно -а)ниі-. Веома често у дипломатском дискурсу срећу се изведени предлози, посебно двокомпонентни са генитивом: в цуелях $+N_{g e n}$ в силу $+N_{g e n}$, као и трокомпонентни са инструменталом: в связи с + $N_{\text {ins }}$ в соответствии $c+N_{\text {ins }}$ и сл. Готово идентично је и у српском језику. Српски еквивалент за конструкцију в силу $+N_{g e n}$ најчешће је стицајем $+N_{g e n}$ или услед $+N_{\text {gen }}$ : в силу исторических обстоятельств (српски: стицајем/услед историјских околности).

Када је реч о глаголима, они се често налазе у облику трећег лица једнине и првог лица множине презента, док се форма инфинитива користи у улози императива. Индикативом презента најчешће се изражава обавеза, док се футуром може изразити извесни степен модалности, која може подразумевати могућност или кондиционалност (Кожина и др. 2011: 320)

Поменућемо и стереотипне конструкције карактеристичне за вербалне ноте.

Клишеи и стереотипне конструкције обавезне су у протоколарним комплиментима на почетку и на крају ноте: «Посольство Республики Сербии свидетельствует своё уважение Министерству иностранных дел Российской Федерации и имеет честь сообщить...» (српски: „Амбасада Републике Србије изражава своје поштовање Министарству иностраних послова Руске Федерације и има част да обавести...”). 
На крају ноте најчешће је у употреби стереотипни закључни протоколарни комплимент: «Посольство пользуется случаем, чтобы возобновить Министерству уверения в весьма высоком уважении» (српски: „Амбасада Републике Србије користи и ову прилику да Министарству понови изразе свог особитог поштовања“).

Синтаксичке конструкције у језику дипломатије одликују се проширеном структуром, као и понављањем синтаксичких средстава, у циљу прецизнијег изражавања потребне информације (Волкова 2011: 23). На нивоу реченице у оба језика употребљавају се конструкције са инфинитивом или да-конструкција за изражавање циља. Уочавамо да су честе не само теличне, већ и кондиционалне, концесивне и декларативне реченице. Употреба декомпонованог предиката карактеристична је за изражавање одмереног тона и етикеције: свидетельствовать почтение, выразить/принять уверение в весьма глубоком уважении. Нису реткост ни партиципске конструкције. У преписци на руском језику честе су пасивне конструкције (нпр. нами/вами будет выполнено). Уочава се нешто ређа употреба зависносложених узрочних реченица, с обзиром на то да дипломатска нота чешће има информативну или протоколарну сврху, а ређе каузативни карактер. Облик императива користи се веома ретко, осим у екстремним случајевима, протестним нотама и сличним ситуацијама.

У зависносложеним реченицама најчешће су у употреби телични (циљни) везници чтобы, с тем, чтобы, для того, чтобы (српски: да + презент/ потенцијал/кондиционал, како би, ради тога да, не би ли), концесивни вопреки тому что, несмотря на то что, невзирая на то что, (српски: упркос томе што, без обзира на то што, и поред тога што), као и кондиционални везници если, если бы (српски: уколико, ако, кад, ако/кад би).

На нивоу стилистике, у дипломатском језику често је присутна метонимија, као у синтагмама: офищиальная Москва, офищиальный Белград, Кремль соглашается, Москва выражает озабоченность (српски: званична Москва, званични Београд, Кремь се слаже, Москва изражава забринутост) и сл.

Поред стереотипних израза, у формулацијама су присутни еуфемизми приликом описивања конкретних ситуација, проблема или ставова, а као што смо раније поменули, карактеристичне су и лексеме којима се изражава прецизност, тактичност, уздржаност, толеранција.

На основу наведених лингвистичких карактеристика руског и српског дипломатског дискурса изводимо закључак да међу њима постоје идентичности и сличности, као и малобројне разлике најпре на лексичком нивоу. Када је реч о пореклу једног броја термина, у српском језику се уочава нешто већи број позајмљеница из латинског и француског (амбасадор, ед-мемоар, акредитиви, коегзистенција), док су у новије време англицизми све бројнији како у руском језику, тако и у српском. На морфолошком нивоу присутна је употреба девербативних именица у оба језика, као и изведених предлога са генитивом и инструменталом, паралелно са стереотипним конструкцијама које су уједно и најчешће у дипломатским нотама. На синтаксичком нивоу руски језик дипломатије одликује се употребом партиципских конструкција које нису карактеристичне за српски језик, док се сличност огледа у употреби зависносложених теличних, 
кондиционалних и концесивних реченица, док су каузалне ређе. По стилу исказа дипломатски дискурс одликује се етикецијом и умереношћу, асертивношћу, а метонимија је честа стилска фигура.

Свакако се може рећи да не постоје суштинске разлике између руског и српског дипломатског дискурса, како на лексичком, тако и на морфолошком, односно синтаксичком језичком нивоу. О извесним разликама може се говорити најпре када је реч о лексици, и то у вези са начином настанка појединих дипломатских термина и фреквентношћу њихове употребе.

С обзиром на то да се у последње време уочава нешто већи број радова из области језика струке, односно језика за специфичне циљеве (LSP), како у руској, тако и у српској литератури, можемо закључити да ова тема заслужује знатно детаљнија даља истраживања.

\section{Цитирана литература}

Авербух, Константин. Общая теория термина. Москва: МГОУ, 2006.

[Averbuh, Konstantin. Obŝaiā teoriiâ termina. Moskva: MGOU, 2006]

Волкова, Татьяна. «Методика анализа дискурса в моделировании перевода дипломатических текстов». Политическая лингвистика 3(37), 2011. 17-24.

[Volkova, Tat'iāna. "Metodika analiza diskursa v modelirovanii perevoda diplomaticheskih tekstov". Politicheskaiā lingvistika 3 (37), 2011. 17-24]

Даниленко, Валерия П. Русская терминология. Опыт лингвистического описания. Москва: Наука, 1977.

[Danilenko, Valeriiā P. Russkaiā terminologiiā. Opyt lingvisticheskogo opisaniā. Moskva: Nauka, 1977]

Кожина, Маргарита Н, Лилия Дускаева Р. Стилистика русского языка. Москва: Флинта; Наука, 2011.

[Kožina, Margarita N, Liliiā Duskaeva R. Stilistika russkogo iāzyka. Moskva: Flinta; Nauka, 2011]

Кончаревић, Ксенија. Руски језик у комуникацији и мисији цркве: Функционални стилови, ресурси, жанрови. Београд: Православни богословски факултет, 2014.

[Končarević, Ksenija. Ruski jezik u komunikaciji i misiji crkve: Funkcionalni stilovi, resursi, žanrovi. Beograd: Pravoslavni bogoslovski fakultet, 2014]

Лейчик, Владимир. Терминоведение: Предмет, методы, структура (4-е изд.). Москва: Книжный дом Либроком, 2009.

[Leǐchik, Vladimir. Terminovedenie: Predmet, metody, struktura (4-e izd.). Moskva: Knizhnyı̌ dom Librokom, 2009]

Лойко, Леонид В. Дипломатическая переписка. Учебно-методическое пособие для студентов специальностей «Международные отношения», «Международное право», «Мировая экономика». Минск: БГУ, 2007.

[Loǐko, Leonid V. Diplomaticheskaiā perepiska. Uchebno-metodicheskoe posobie dlia studentov spetsial'nostě̌ «Mezhdunarodnye otnosheniiā», «Mezhdunarodnoe pravo», «Mirovaia èkonomika». Minsk: BGU, 2007] 
Ружица Радойчич

\title{
ЛИНГВИСТИЧЕСКИЕ ОСОБЕННОСТИ РУССКОГО И СЕРБСКОГО ДИПЛОМАТИЧЕСКОГО ДИСКУРСА
}

\begin{abstract}
Резюме
В данной статье рассматриваются наиболее важные особенности дипломатического дискурса на материале русского и сербского языков, охватывая все уровни языка, а также сербские переводные эквиваленты. Язык дипломатии, как субстиль официально-делового функционального стиля представляет собой стандартизированную систему языковых единиц для специальных целей, функция которых проявляется в области международных сношений.

Анализ показал, что на лексическом уровне в русском и сербском языках присутствуют лексемы славянского и неславянского происхождения, на морфологическом уровне в обоих языках имеют место отглагольные существительные, производные предлоги с родительным и творительным падежами, наряду со стереотипными конструкциями. Синтаксический уровень характеризуется употреблением причастий в русском языке (в отличие от сербского), а также предложениями с придаточным цели, условия, уступки. В меньшей мере употребляются предложения с придаточным причины. Стилистический уровень в обоих языках характеризуется речевым этикетом, тактом, ассертивностью, сдержанностью, а также метонимичностью.

Ключевые слова: язык для специальных целей (LSP), язык дипломатии, стереотипные конструкции, речевой этикет, лексика, морфология, синтаксис, стилистика, переводные эквиваленты.
\end{abstract}

